\title{
Effect of Sowing Date and Chemical Foliar Sprays on Productivity and Cold Injury Management of Castor (Ricinus communis L.) in Western Haryana region, India
}

\author{
P.S. John Daniel*, J.S. Yadav, Jagdev Singh and K.D. Sharma \\ Department of Agronomy, CCS Haryana Agricultural University, \\ Hisar-125004, Haryana, India \\ *Corresponding author
}

\section{A B S T R A C T}

\begin{abstract}
A field experiment was carried out in consecutive years of 2013-14 and 2014-15 conducted at regional research station, Bawal, CCS Haryana Agricultural University to study effect of sowing time and chemical foliar sprays on the productivity and cold injury management in castor (Ricinus communis L.). The experiment was laid out in split plot design on loamy sand soil. Treatments comprised of four dates of sowing viz., $20^{\text {th }}$ June, $5^{\text {th }}$ July, $20^{\text {th }}$ July and $5^{\text {th }}$ August and four chemical foliar sprays along with water and no spray check viz., DMSO $\left(78 \mathrm{ml} \mathrm{ha}^{-1}\right), \mathrm{H}_{2} \mathrm{SO}_{4}(0.1 \%)$, Thiourea $500 \mathrm{ppm}$, Salicylic acid 100 ppm that are replicated thrice. Among the different dates of sowing, $20^{\text {th }}$ June resulted in significantly higher growth and yield parameters during 2013-14 and 2014-15 crop seasons compared to other dates of sowing. $20^{\text {th }}$ June date of sowing produced significantly higher grain yield i.e., $5157 \mathrm{~kg} \mathrm{ha}^{-1}$ during 2013-14 and $5412 \mathrm{~kg} \mathrm{ha}^{-1}$ during 2014-15 as well pooled grain yield $5285 \mathrm{~kg} \mathrm{ha}^{-1}$ as compared to the $20^{\text {th }}$ July and $5^{\text {th }}$ August sowing dates. Application of $\mathrm{H}_{2} \mathrm{SO}_{4}(0.1 \%)$ showed significantly substantial effect on grain yield (4703 $\mathrm{kg} \mathrm{ha}^{-1}$ ) during 2013-14 and during 2014-15 (4869 $\mathrm{kg} \mathrm{ha}^{-1}$ ) as well as on pooled basis (4786 $\mathrm{kg} \mathrm{ha}^{-1}$ ) compared to the foliar sprays. Sowing during $20^{\text {th }}$ June along with application of $\mathrm{H}_{2} \mathrm{SO}_{4}(0.1 \%)$ registered higher relative water, leaf water potential, chlorophyll index and lower membrane injury as compared to different sowing dates and chemical foliar sprays during 2013-14 and 2014-15 crop seasons. In economic analysis of two year data, profitability of castor in terms of returns was substantially high in $20^{\text {th }}$ June date of sowing with gross returns (Rs. $203702 \mathrm{ha}^{-1}$ and $216480 \mathrm{ha}^{-1}$ ), net returns (Rs. $150622 \mathrm{ha}^{-1}$ and $163809 \mathrm{ha}^{-1}$ ) and $\mathrm{B}: \mathrm{C}$ ratio (3.84 and 4.11) as compared to other sowing dates. Among the chemical foliar sprays, $\mathrm{H}_{2} \mathrm{SO}_{4}(0.1 \%)$ significantly recorded higher gross returns (Rs. $185769 \mathrm{ha}^{-1}$ and Rs. $196080 \mathrm{ha}^{-1}$ ), net returns (Rs. $130759 \mathrm{ha}^{-1}$ and Rs. $141479 \mathrm{ha}^{-1}$ ) and B: C ratio (3.39 and 3.59, respectively) when compared to other foliar sprays.
\end{abstract}

\section{Keywords}

Castor, DCH-177, Foliar sprays, Cold injury, Economics, B: C ratio

Article Info

Accepted:

18 October 2018

Available Online:

10 November 2018

\section{Introduction}

India is one of the largest producers of nonedible oil seeds in the world. Castor is an important non-edible oil seed crop of India playing a pivotal role in the agrarian economy. The oil extracted from the castor already has a demonstrated market, guaranteed by variety of 
700 uses, ranging from medicines and cosmetics to replacing petroleum by biodiesel, plastics and lubricants (Anonymous, 2003; Mario Osava, 2003). It is used as a lubricant in high-speed engines and aeroplanes, in the manufacture of soaps, transparent paper, printing-inks, varnishes, linoleum and plasticizers and also for medicinal and lighting purposes. Despite phenomenal increase in the production and productivity of castor over the past decade, there is wide disparity in productivity among various growing regions of India.

India currently produces $16,44,000$ tonnes of castor seed compared to world castor production of 18,65,447 tonnes (FAOSTAT, 2013). Although Haryana holds very less in terms of area (2000 ha) and production (3000 tonnes) but productivity of castor is quite high in Haryana (1500 kg ha ${ }^{-1}$ ) as comparable to leading states like Gujarat $\left(1988 \mathrm{~kg} \mathrm{ha}^{-1}\right)$ and Rajasthan (1530 kg ha ${ }^{-1}$ (INDIASTAT, 2013). The variety DCH-177 exhibit enormous results and reaping better yields under irrigated conditions in Bawal region, Haryana. Despite higher castor productivity in Haryana, cold injury is the major limiting factor.

Low temperature adversely affects the seed quality by reducing the seed size attributed to mobilization of photo assimilates leading to yield reduction, thereby widening the gap between the potential and actual yield. Therefore, generating recommendations for cold injury management will not only ensure higher productivity and profitability but will also help in accelerated adoption of this crop in Western Haryana region. Keeping the above points in view, the present field experiment was conducted with objective to study of effect of sowing time and chemical foliar sprays on the productivity and cold injury management in castor (Ricinus communis L.).

\section{Materials and Methods}

The field experiment was conducted at regional research station, Bawal, CCS Haryana Agricultural University during 201314 and 2014-15 crop seasons. Treatments comprised of four dates of sowing viz., $20^{\text {th }}$ June, $5^{\text {th }}$ July, $20^{\text {th }}$ July and $5^{\text {th }}$ August and four chemical foliar sprays along with water and no spray check viz., DMSO (78 $\left.\mathrm{ml} \mathrm{ha}^{-1}\right)$, $\mathrm{H}_{2} \mathrm{SO}_{4}(0.1 \%)$, Thiourea 500 ppm, Salicylic acid $100 \mathrm{ppm}$ that are replicated thrice. The soil of the experiment is loamy sand in

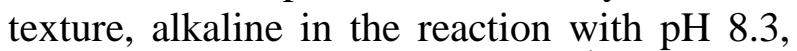
available nitrogen $148 \mathrm{~kg} \mathrm{ha}^{-1}$, available phosphorous $15 \mathrm{~kg} \mathrm{ha}{ }^{-1}$, and available potassium $182 \mathrm{~kg} \mathrm{ha}^{-1}$, respectively. All the treatments were supplied with recommended dose fertilizers i.e., $80 \mathrm{~kg} \mathrm{~N}, 50 \mathrm{~kg} \mathrm{P}_{2} \mathrm{O}_{5}$ in form of urea and DAP. Half of $\mathrm{N}\left(40 \mathrm{~kg} \mathrm{ha}^{-1}\right)$ and full dose of $\mathrm{P}_{2} \mathrm{O}_{5}\left(50 \mathrm{~kg} \mathrm{ha}^{-1}\right)$ was applied as basal dose and remaining 50 percent $\mathrm{N}$ (40 $\mathrm{kg} \mathrm{ha}^{-1}$ ) was top dressed in two equal splits at 120 days crop growth stage and 30 days thereafter. Seeds were scarified by rubbing against rough surface to enhance germination. Seeds were soaked before sowing in water for 24 hours and dried under shade before sowing. Seeds were treated with carbendazim @ $1 \mathrm{~g} \mathrm{~kg}$ ${ }^{1}$ of seed to protect from seed borne diseases. The spacing adopted was $120 \times 90 \mathrm{~cm}$. The crop was kept free from diseases through suitable protection measures. The crop was harvested in six to seven pickings manually based on physiological maturity of the capsules. Total rainfall of 797.5 and $860.9 \mathrm{~mm}$ was received during 2013-14 and 2014-15 crop seasons.

\section{Results and Discussion}

\section{Growth parameters}

Sowing the crop on $20^{\text {th }}$ June (122.7 and 120.8 $\mathrm{cm}$ ) resulted in taller plants in comparison with that sown on $5^{\text {th }}$ July, $20^{\text {th }}$ July and $5^{\text {th }}$ 
August, but $5^{\text {th }}$ July found in comparable with early sowing date (Table 1). The present findings corroborate with reports of Sreedhar and Yakadri (2004) and Reddy et al., (2007). Similar trend was observed in leaf area index and dry matter production. Higher leaf area index was noticed during early sowing date i.e., $20^{\text {th }}$ June sowing (4.03 and 4.22) might due to the better foliage development and favourable weather conditions during crop growth period than delayed sowing. Dry matter production of the crop sown during $20^{\text {th }}$ June (789.4 and $804.9 \mathrm{~g} \mathrm{plant}^{-1}$ ) was higher and found to be superior compared to remaining dates of sowing and plant stand observed non significant variation at 90 DAS among the sowing dates (Table 1). Delay in sowing every fort night resulted in decrease in dry matter production of 28.6 per cent and 27.5 per cent observed in $5^{\text {th }}$ August date of sowing. Similar conclusions are drawn also by Reddy et al., (2007).

Application of $\mathrm{H}_{2} \mathrm{SO}_{4}(0.1 \%)$ resulted in higher leaf area index and showed substantial effect followed by DMSO (78 $\left.\mathrm{ml} \mathrm{ha}^{-1}\right)$ compared to other chemical foliar sprays at $25^{\text {th }}$ February. This may be due to the increase in water soluble carbohydrate and protein status of the plants that have strong influence on cryoprotection phenomenon (Volger and Heber, 1975). Our findings are similar with Levitt et al., (1962); Porwal et al., (1986); Rao and Sahu (1991) also reported that application of $\mathrm{H}_{2} \mathrm{SO}_{4}$ and DMSO was effective in cryoprotection of the chickpea.

\section{Yield attributes}

Sowing during $20^{\text {th }}$ June (17.3 and 19.4) recorded substantially higher number of spikes plant $^{-1}$ when compared to $5^{\text {th }}$ July (16.6 and 17.2), $20^{\text {th }}$ July (15.9 and 16.5) and $5^{\text {th }}$ August (12.6 and 15.6) sowing dates (Table 2). There was enhancement in higher number of spikes plant $^{-1}$ by $37.3 \%$ and $24.3 \%$ as compared to $5^{\text {th }}$ August date of sowing. Nagabhushanam and
Raghavaiah (2005) also reported the similar observations with regard to number of spikes plant $^{-1}$ under varied sowing dates. The number of capsules primary spike ${ }^{-1}$ progressively increased towards the delayed date of sowing i.e., $5^{\text {th }}$ August recorded higher number of capsules primary spike ${ }^{-1}(7.2 \%$ and $4.4 \%)$ than $20^{\text {th }}$ June date of sowing (Table 2). This may be attributed to low temperature prevailed during the vegetative growth to low plant stature and dry matter accrual corresponding with quantity of assimilates diverted to sink, which results in elevated stature of capsules production. Higher primary spike length and 100 seed weight were also noticed with $5^{\text {th }}$ August sowing in comparison to the earlier sowing dates due to loosening of the capsules and partitioning diverted towards the primary spike and provided sufficient time for higher production of photosynthates ultimately leads to increase in weight of the seed of primary spike. The present findings are in contrary with those of Reddy et al., (2007) and Nagabhushanam and Raghavaiah (2005). Application of $\mathrm{H}_{2} \mathrm{SO}_{4} \quad(0.1 \%)$ resulted in substantially higher number of spikes plant ${ }^{-1}$ as compared to than chemical foliar sprays during both the crop seasons. This could be due to increase in water soluble carbohydrate and protein status of the plants. Similar findings are reported by Levitt et al., (1962), Porwal et al., (1986) and Rao and Sahu (1991).

\section{Seed yield}

Sowing the crop during $20^{\text {th }}$ June $\left(5157 \mathrm{~kg} \mathrm{ha}^{-}\right.$ ${ }^{1}$ and $5412 \mathrm{~kg} \mathrm{ha}^{-1}$ ) recorded the highest seed yield followed by $5^{\text {th }}$ July (5094 $\mathrm{kg} \mathrm{ha}^{-1}$ and $5264 \mathrm{~kg} \mathrm{ha}^{-1}$ ) yield which was significantly higher than $20^{\text {th }}$ July and $5^{\text {th }}$ August sowing dates (Table 3). Lowest seed yield was recorded in delayed sowing i.e., $5^{\text {th }}$ August date of sowing. Delay in sowing resulted in decrease of grain yield of 43.6 per cent when compared to early sowing date. The increase 
Table.1 Growth parameters of castor as influenced by various dates of sowing

\begin{tabular}{|c|c|c|c|c|c|c|c|c|}
\hline \multirow[t]{2}{*}{ Treatments } & \multicolumn{2}{|c|}{$\begin{array}{c}\text { Plant height }(\mathrm{cm}) \text { at } \\
120 \text { DAS }\end{array}$} & \multicolumn{2}{|c|}{ Leaf area index } & \multicolumn{2}{|c|}{$\begin{array}{l}\text { Dry matter accumulation } \\
\qquad\left(\mathrm{g} \text { plant }^{-1}\right)\end{array}$} & \multicolumn{2}{|c|}{$\begin{array}{c}\text { Plant population } \\
\left(000^{\prime} / \text { ha }\right) \text { At } 90 \text { DAS }\end{array}$} \\
\hline & 2013 & 2014 & 2013 & 2014 & 2013 & 2014 & 2013 & 2014 \\
\hline \multicolumn{9}{|c|}{ Dates of sowing } \\
\hline $20^{\text {th }}$ June & 122.7 & 120.8 & 4.03 & 4.22 & 773.9 & 804.9 & 9.22 & 9.23 \\
\hline $5^{\text {th }}$ July & 116.6 & 114.1 & 3.89 & 4.03 & 734.2 & 765.2 & 9.22 & 9.22 \\
\hline 20th July & 114.7 & 102.9 & 3.75 & 3.79 & 619.9 & 650.9 & 9.22 & 9.23 \\
\hline $5^{\text {th }}$ August & 96.1 & 84.1 & 3.15 & 3.35 & 552.8 & 583.8 & 9.20 & 9.22 \\
\hline SEm \pm & 0.7 & 1.8 & 0.04 & 0.05 & 1.36 & 1.34 & 0.01 & 0.02 \\
\hline $\mathrm{CD}(\mathrm{P}=0.05)$ & 2.6 & 6.3 & 0.14 & 0.19 & 4.80 & 4.74 & NS & NS \\
\hline
\end{tabular}

Table.2 Yield attributes of castor as influenced by various dates of sowing

\begin{tabular}{|c|c|c|c|c|c|c|c|c|}
\hline \multirow[t]{2}{*}{ Treatments } & \multicolumn{2}{|c|}{$\begin{array}{l}\text { Length of the } \\
\text { primary spike }(\mathrm{cm})\end{array}$} & \multicolumn{2}{|c|}{$\begin{array}{c}\text { Number of capsules } \\
\text { primary spike }\end{array}$} & \multicolumn{2}{|c|}{$\begin{array}{l}\text { Number of spikes } \\
\text { plant }^{-1} \text { at harvest }\end{array}$} & \multicolumn{2}{|c|}{100 Seed weight } \\
\hline & 2013 & 2014 & 2013 & 2014 & 2013 & 2014 & 2013 & 2014 \\
\hline \multicolumn{9}{|c|}{ Dates of sowing } \\
\hline $20^{\text {th }}$ June & 64.5 & 54.7 & 76.7 & 79.6 & 17.3 & 19.4 & 28.6 & 29.0 \\
\hline $5^{\text {th }}$ July & 62.3 & 59.5 & 79.1 & 79.2 & 16.6 & 17.2 & 29.4 & 29.2 \\
\hline 20th July & 68.6 & 59.5 & 80.6 & 81.6 & 15.9 & 16.5 & 30.7 & 31.8 \\
\hline $5^{\text {th }}$ August & 74.9 & 71.3 & 82.2 & 83.1 & 12.6 & 15.6 & 31.7 & 32.2 \\
\hline SEm \pm & 0.7 & 1.2 & 0.4 & 1.2 & 0.4 & 0.1 & 0.2 & 0.1 \\
\hline $\mathrm{CD}(\mathrm{P}=0.05)$ & 2.7 & 4.4 & 1.5 & 4.4 & 1.3 & 0.4 & 0.7 & 0.5 \\
\hline
\end{tabular}


Table.3 Seed yield, Stalk yield and Biological yield of castor as influenced by various dates of sowing and chemical foliar sprays

\begin{tabular}{|c|c|c|c|c|c|c|c|c|c|}
\hline \multirow[t]{2}{*}{ Treatments } & \multicolumn{3}{|c|}{ Seed yield $\left(\mathrm{kg} \mathrm{ha}^{-1}\right)$} & \multicolumn{3}{|c|}{ Stalk yield $\left(\mathrm{kg} \mathrm{ha}^{-1}\right)$} & \multicolumn{3}{|c|}{ Biological Yield $\left(\mathrm{kg} \mathrm{ha}^{-1}\right)$} \\
\hline & 2013 & 2014 & $\begin{array}{c}\text { Pooled } \\
\text { data }\end{array}$ & 2013 & 2014 & $\begin{array}{c}\text { Pooled } \\
\text { data }\end{array}$ & 2013 & 2014 & $\begin{array}{c}\text { Pooled } \\
\text { data }\end{array}$ \\
\hline \multicolumn{10}{|l|}{ Dates of sowing } \\
\hline $20^{\text {th }}$ June & 5,157 & 5,412 & 5,285 & 7,625 & 8,129 & $\mathbf{7 , 8 7 7}$ & 12,782 & 13,541 & 13,162 \\
\hline $5^{\text {th }}$ July & 5,094 & 5,264 & 5,179 & 7,542 & 7,946 & 7,744 & 12,636 & 13,210 & 12,923 \\
\hline $20^{\text {th }}$ July & 4,410 & 4,558 & 4,484 & 6,665 & 6,822 & 6,743 & 11,075 & 11,380 & 11,227 \\
\hline $5^{\text {th }}$ August & $\mathbf{3 , 5 7 2}$ & 3,787 & 3,680 & 5,478 & 5,683 & 5,580 & $\mathbf{9 , 0 5 0}$ & $\mathbf{9 , 4 7 0}$ & 9,260 \\
\hline SEm \pm & 34 & 47 & 19 & 42 & 59 & 46 & 76 & 98 & 79 \\
\hline $\mathrm{CD}(\mathrm{P}=0.05)$ & 122 & 165 & 67 & 149 & 207 & 164 & 268 & 344 & 279 \\
\hline \multicolumn{10}{|l|}{ Chemical foliar sprays } \\
\hline DMSO (78 ml/ha) & 4,673 & 4,851 & 4,762 & 6,953 & 7,269 & 7,111 & 11,626 & 12,120 & 11,873 \\
\hline Sulphuric acid $(0.1 \%)$ & 4,703 & 4,869 & 4,786 & 7,089 & 7,278 & 7,184 & 11,792 & 12,147 & 11,970 \\
\hline Thio-urea (500 ppm) & 4,549 & 4,859 & 4,704 & 6,811 & 7,257 & 7,034 & 11,360 & 12,116 & $\mathbf{1 1 , 7 3 8}$ \\
\hline Salicylic acid (100 ppm) & 4,537 & 4,739 & 4,638 & 6,802 & 7,131 & 6,967 & 11,339 & 11,870 & 11,605 \\
\hline Water spray & 4,466 & 4,666 & 4,566 & 6,681 & 7,004 & 6,842 & 11,147 & 11,670 & 11,408 \\
\hline Control & 4,420 & 4,548 & 4,484 & 6,630 & 6,782 & 6,706 & 11,049 & 11,330 & 11,190 \\
\hline SEm \pm & 32 & 41 & 27 & 52 & 42 & 31 & 79 & 70 & 49 \\
\hline $\mathrm{CD}(\mathrm{P}=0.05)$ & 93 & 119 & 78 & 148 & 121 & 89 & 225 & 201 & 141 \\
\hline
\end{tabular}


Table.4 Economics of castor as influenced by various dates of sowing and chemical foliar sprays

\begin{tabular}{|c|c|c|c|c|c|c|c|c|}
\hline \multirow[b]{2}{*}{ Treatments } & \multicolumn{4}{|c|}{2013} & \multicolumn{4}{|c|}{2014} \\
\hline & $\begin{array}{c}\text { Gross } \\
\text { Returns } \\
\left(\text { Rs ha }^{-1}\right)\end{array}$ & $\begin{array}{c}\text { Cost of } \\
\text { cultivation }\end{array}$ & $\begin{array}{c}\text { Net } \\
\text { Returns } \\
\left(\text { Rs ha }^{-1}\right)\end{array}$ & $\begin{array}{l}\text { B: C } \\
\text { Ratio }\end{array}$ & $\begin{array}{c}\text { Gross } \\
\text { Returns } \\
\left(\text { Rs ha }^{-1}\right)\end{array}$ & $\begin{array}{c}\text { Cost of } \\
\text { cultivation }\end{array}$ & $\begin{array}{c}\text { Net } \\
\text { Returns } \\
\left(\text { Rs ha }^{-1}\right)\end{array}$ & $\begin{array}{l}\text { B: C } \\
\text { Ratio }\end{array}$ \\
\hline \multicolumn{9}{|l|}{ Dates of sowing } \\
\hline $20^{\text {th }}$ June & $2,03,702$ & 53,080 & $\mathbf{1 , 5 0 , 6 2 2}$ & 3.84 & $2,16,480$ & 52671 & $\mathbf{1 , 6 3 , 8 0 9}$ & 4.11 \\
\hline $5^{\text {th }}$ July & $2,01,213$ & 53,080 & $1,48,133$ & 3.79 & $2,10,560$ & 52671 & $\mathbf{1 , 5 7 , 8 8 9}$ & 4.00 \\
\hline $20^{\text {th }}$ July & $1,74,195$ & 53,080 & $1,21,115$ & 3.28 & $\mathbf{1 , 8 2 , 3 2 0}$ & 52671 & $1,29,649$ & 3.46 \\
\hline $5^{\text {th }}$ August & $1,41,094$ & 53,080 & 88,014 & 2.66 & $\mathbf{1 , 5 1 , 4 8 0}$ & 52671 & 98,809 & 2.88 \\
\hline SEm \pm & - & - & - & - & - & - & - & - \\
\hline $\mathrm{CD}(\mathrm{P}=0.05)$ & - & - & - & - & - & - & - & - \\
\hline \multicolumn{9}{|l|}{ Chemical foliar sprays } \\
\hline DMSO (78 ml/ha) & $1,84,584$ & 54,565 & $\mathbf{1 , 3 0 , 0 1 9}$ & 3.38 & $1,94,040$ & 54156 & $1,39,884$ & 3.58 \\
\hline Sulphuric acid (0.1\%) & $1,85,769$ & 55,010 & $1,30,759$ & 3.39 & $1,96,080$ & 54601 & $1,41,479$ & 3.59 \\
\hline Thio-urea (500 ppm) & $1,79,686$ & 55,167 & $1,24,519$ & 3.26 & $1,93,000$ & 54758 & $1,38,242$ & 3.52 \\
\hline $\begin{array}{l}\text { Salicylic acid (100 } \\
\text { ppm) }\end{array}$ & $1,79,212$ & 55,617 & $1,23,595$ & 3.22 & $1,87,600$ & 54207 & $1,33,393$ & 3.46 \\
\hline Water spray & $\mathbf{1 , 7 6 , 4 0 7}$ & 54,480 & $1,21,927$ & 3.20 & $\mathbf{1 , 8 6 , 2 8 0}$ & 54071 & $1,32,209$ & 3.43 \\
\hline Control & $\mathbf{1 , 7 4 , 5 9 0}$ & 53,080 & $1,21,510$ & 3.18 & $1,84,280$ & 52671 & $1,31,609$ & 3.40 \\
\hline SEm \pm & - & - & - & - & - & - & - & - \\
\hline $\mathrm{CD}(\mathrm{P}=0.05)$ & - & - & - & - & - & - & - & - \\
\hline
\end{tabular}


in yield may be attributed to more number of effective spikes and higher dry matter production of crop elevated yield structure resulting in higher yield. The yield reductions in castor with delayed sowings were also observed by Reddy et al., (2007) and Nagabhushanam and Raghavaiah (2005).

Application of $\mathrm{H}_{2} \mathrm{SO}_{4}(0.1 \%)$ resulted in higher seed yield and showed substantial effect followed by $78 \mathrm{ml} \mathrm{ha}^{-1}$ DMSO among chemical foliar sprays. This may be due to the increase in water soluble carbohydrate and protein status of the plants that have strong influence on cryo protection phenomenon (Volger and Heber, 1975). Dashora (1980) also reported that low temperature injury in potato plants treated with $\mathrm{H}_{2} \mathrm{SO}_{4}$ had significantly higher water soluble carbohydrates and protein contents by 22.77 and 18.18 per cent over control and tuber yield was increased by 50.42 per cent over no spray check. The present findings are similar with those of Levitt et al., (1962); Porwal et al., (1986); Rao and Sahu (1991) who reported that application of $\mathrm{H}_{2} \mathrm{SO}_{4}$ and DMSO were effective in cryo protection of the chickpea.

Application of chemical foliar sprays showed substantial effect over varied dates of sowings Application of $\mathrm{H}_{2} \mathrm{SO}_{4}(0.1 \%)$ followed by DMSO $\left(78 \mathrm{ml} \mathrm{ha}^{-1}\right)$ registered more relative water content, Higher water potential and chlorophyll index among the different chemical foliar sprays. Reduced membrane injury also observed with application of $\mathrm{H}_{2} \mathrm{SO}_{4}(0.1 \%)$ and proved to be better chemical foliar spray under low temperature stress during both the years.

\section{Economics}

Economic analysis of various sowing dates under test showed that the maximum gross returns (Rs. 203702 and $216480 \mathrm{ha}^{-1}$ ) and net returns (Rs. $150622 \mathrm{ha}^{-1}$ and $163809 \mathrm{ha}^{-1}$ ) are noticed highest with $20^{\text {th }}$ June sowing when compared other dates of sowing (Table 4). This might be attributed with timely establishment of crops which improved crop yield resulting in higher gross and net returns. The highest B: C ratio was registered with early sowing date i.e., $20^{\text {th }}$ June (3.84 and 4.11) when compared to $5^{\text {th }}$ July (3.79 and 4.00), $20^{\text {th }}$ July (3.28 and 3.46) and $5^{\text {th }}$ August (2.66 and 2.88). The present findings are in conformity with Cheema et al., (2013).

The gross returns, net returns as well as B: C ratio improved with application of chemical foliar sprays over the no spray check. Application of $\mathrm{H}_{2} \mathrm{SO}_{4} \quad(0.1 \%)$ registered highest gross returns, net returns and $\mathrm{B}$ : $\mathrm{C}$ ratio among all the chemical foliar sprays. This might be attributed to better control of cold injury compared to other chemical foliar sprays. Similar findings were made by Porwal et al., (1986), Rao and Sahu (1991) and Manohar Lal (2013).

In economic analysis of two year data, profitability of castor in terms of returns was substantially high in $20^{\text {th }}$ June date of sowing and $\mathrm{H}_{2} \mathrm{SO}_{4}(0.1 \%)$ chemical foliar spray showed substantial effect on cold injury under various sowing dates and chemical foliar sprays.

From the present investigation, it may be concluded that $20^{\text {th }}$ June date of sowing is found to be better suitable time for growing of castor with respect to growth, yield and agrophysiological traits as compared to other sowing dates. $\mathrm{H}_{2} \mathrm{SO}_{4}(0.1 \%)$ is found be best management practice to avoid cold injury in castor with respect to growth, yield and agrophysiological traits. Sowing of castor in $20^{\text {th }}$ June date of sowing and application of $\mathrm{H}_{2} \mathrm{SO}_{4}$ $(0.1 \%)$ found to be a better profitable system under various sowing dates and chemical foliar sprays to avoid cold injury in Western Haryana region. 


\section{References}

Cheema, NM., Farroq, U., Shabbir, G., Shah, MKN and Musa, M., 2013. Prospects of castor bean cultivation in rainfed tract of Pakistan. Pak. J. Bot., 45: 219-224.

Dashora, S.S., 1980. Prevention of low temperature injury in potato (Solanum tuberosum L.) by chemical means. $M$. Sc. Thesis, Department of Agronomy, University of Udaipur.

FAOSTAT., 2013. Food and Agriculture Organization of the United Nations (FAO) statistical databases. Rome, Italy. http://www.fao.org.

INDIASTAT., $2013 . \quad \mathrm{http}: / / \mathrm{www}$. Indiastat.com

Levitt, J., 1962. A sulfhydral disulphide hypothesis of frost injury and resistance in plants. J. Theo. Bio., 3: 335-391.

Manohar Lal, 2013. Physiological and biochemical responses to low temperature in chickpea (Cicer arientinum L.). M. Sc. (Ag.) Thesis, CCS Haryana Agricultural University, Hisar, Haryana.

Nagabhushanam, U and Raghavaiah, CV., 2005. Seeding date and irrigation effects on the productivity and oil quality of post monsoon grown castor (Ricinus communis L.) in Alfisols. J. Oilseeds. Res., 22: 206-208.

Porwal, B.L., Singh, H.G. and Mathur, P.N., 1986. Metabolic changes associated with chemical cryoprotection in gram (Cicer arietinum L.). Biochemie und Physiologie Pflanzen, 181: 659-664

Rao, S.S. and Sahu, M.P., 1991. Effect of sulphur and foliar-applied chemicals on cold tolerance in chickpea (Cicer arientinum L.). J. Agro. Crop Sci., 167: 320-325.

Reddy, UVB., Reddy, GP and Reddy, DS., 2007. Effect of seeding time on productivity of castor (Ricinus communis L.) cultivars in southern agro-climatic zone of Andhra Pradesh. J. Oilseeds. Res., 24: 280-282.

Sreedhar, C and Yakadri M., 2004. Sowing date and genotype effects on performance of rabi castor (Ricinus communis L.) in alfisols. J. Res., ANGRAU 32: 90-92.

Volger, H.G. and Heber, U., 1975. Protective leaf protein. Biochemica et. Biophysica Acta, 412: 335-349.

\section{How to cite this article:}

John Daniel, P.S., J.S. Yadav, Jagdev Singh and Sharma, K.D. 2018. Effect of Sowing Date and Chemical Foliar Sprays on Productivity and Cold Injury Management of Castor (Ricinus communis L.) in Western Haryana region. Int.J.Curr.Microbiol.App.Sci. 7(11): 2447-2454. doi: https://doi.org/10.20546/ijcmas.2018.711.279 